\title{
LEGAL REVIEW OF MANAGEMENT RIGHTS IN THE CREATIVE WORK LAW (LAND CLUSTER)
}

https://doi.org/10.47743/jopafl-2021-19-17

\author{
I Made PRIA DHARSANA \\ Faculty of Law, Udayana University, Denpasar, \\ Bali, Indonesia \\ dharsanaimade@yahoo.com
}

\section{Gusti Agung Jordika PRAMANDITYA}

Faculty of Law, Udayana University, Denpasar,

Bali, Indonesia

\begin{abstract}
This paper will explain related land policies, among others, manifested through the concept of granting Management Rights (HPL) with a term of 90 Years in the Cipta Kerja Law wth the aim of attracting forein investors who are expected to have an impact on the resilience and state land in the form land monopoly. the question is whether the Management Right is the right to control the state over land or land rights. this is because managemen rights are not stated in the Basic Agrarian Law, but are mentioned in management. and we must understand that HPL does not have a legal basis that's is in accordance with the hierarchy of laws and regulations is also in substance contrary to the main procedural objectives of the basic regulations. As a result, long before the Omnibuslaw was born HPL caused a lot of controversion and many problems in practice. As a result, long before the Omnibuslaw was born, HPL Caused a lot of controversy and problems in practice. Many cases due to HPL, occur everywhere. the existence of HPL must be addressed, especially in the legal system, given the right legal basis, or eliminated altogether. so that framework of regulatory structures can be created that is truly harmonized with good rules as a basic philosophical foundation as the basis for a comprehensive arrangement. so that it can align the objectives not only to advance the economic aspect of investment but also to reduce the gap and direct distribution of land use and management through an institutional called the Land Bank.
\end{abstract}

Keywords : Legal Review, Work Law, Land Cluster.

\section{Introduction}

The policy of The Government of Ir. Joko Widodo, to improve economic development, takes into account its influence on national land. But looking at the policy of land law through agrarian politics, it was not accompanied by the structuring of the legal system. As a result many provisions of land law overlap. In the process of establishing a legal system (lawmaking) against the birth of the Omnibuslaw Law, especially land clusters there are indications that there has been politicization of the law, at least in the regulation of HPL (Management Rights). In the Basic Agrarian Law of 1960 there are no rules on Management Rights (HPL). As a result, HPL has caused chaos of land tenure, because it is a form of perversion of the right to control of the state (HMN). In fact, in the Decision of the Court No.001-021-022/PUU-1/2003 that HMN means the policy of regulation, management, management and supervision referring to Article 33 Paragraph 3, and does not mean the state owns the land. While in the Copyright Act, HPL as a granting of rights 
on state land such as wanting to revive the concept of domein verklaring colonial era, which has been removed in the 1960 UUPA.

According to Professor of Faculty of Law, Gajahmada University, Yogyakarta, Prof. Dr. Maria S.W. Sumardjono., S.H., MCL., MPA, long before Omnibuslaw was born in his book entitled "Reflections on Various Land Policies" (2020) has skinned the land policy implemented by the government. Prof Maria said the regulation on Management Rights (HPL) was not intended to straighten out the concept of HPL as a "function" of management, but instead to establish it as a civil "right" as shown in the title "Strengthening Management Rights". Crucial issues include (Maria, 2008):

(1) violate Article 28 of the ACT, as it governs that HGU may be administered on HPL land; (2) the arrangement of the legal relationship between HPL holders and third parties utilizing

(2) a portion of HPL land and its authority, denying the regulation on the position of HPL as an asset (BMN/D or SOE/D);

(3) the period of land rights on HPL land shall be granted at once for 90 years and in certain circumstances the granting of land rights on HPL land can be granted an extension at once.

According to Prof Maria, increasing the attractiveness of investment by granting 90 years of land rights or extension of rights at once with the granting, it clearly violates the Constitution. Ease can be given through simplification of administration, for example the application for extension of rights can be done 5 years before the right expires (see Regulation of the Minister of Agrarian affairs and Spatial Planning / Head of BPN No. 7 of 2017 Arrangements and Procedures for Determination of Business Rights) to be processed his Decree, but the extension of his rights is granted simultaneously with his registration.

Furthermore, to restore HPL as a public management "function", it must be done by:

(1) the affirmation that Property Rights, Building Rights, and Usage Rights can be granted above the Management Rights (HPL), but business rights (HGU) can still only be granted on state land in accordance with the Law - Agrarian Basic Law (UUPA);

(2) The authority of third parties to perform legal actions through the utilization of part of the Land Management Rights (HPL), shall be submitted to the provisions on the utilization of Management Rights (HPL) as assets in accordance with applicable laws and regulations, outside the land law regime.

The government in this case has deviated the implementation of the Basic Agrarian Law (UUPA 5/1960), and explored land policy by quibble for the benefit of the state and investment. And by using the authority owned, the government acts on behalf of the State, which at the highest level holds power over the land to carry out the liberation and revocation of people's land in the national interest. The national interest, elastically interpreted according to the will of the ruler. Furthermore, the author argues that there is an over-interpretation of the Right to Control of The State on Land, and the disresues of the principles of the UUPA that are packaged in agrarian political policy by the government, both in the form of legislation and its implementing regulations have created overlapping regulations and led to inequalities and injustices in the social and economic fields of society (Harsono, 1997). 
Since the beginning, the presence of this omnibus law raises a variety of concerns, among others, potentially causing many agrarian problems. The contents of the omnibus law are considered by various experts and academics, as well as researchers, considered to be inclined to side with businesses and potentially further complicate the implementation of agrarian reform. Concern over the chaos in national land law has actually occurred since the Era of the New Order Government, which then led to the People's Consultative Assembly (MPR), issuing Decree IX / 2001 on Agrarian Reform and Natural Resource Management. The spirit of this MPR Decree is to restore land regulations referring back to the 1945 Constitution and the UUPA.

Quoting Eko Cahyono's statement from the Sajogjo Institute through the Mongabay environmental site, he said that the agrarian problem in Indonesia is inequality in land tenure and conflicts continue to occur. This condition is not properly answered by the Job Creation Law (UU Cipta Kerja. Meanwhile, Prof. Dr. Maria S.W. Sumardjono, Professor of the Faculty of Law, Gadjah Mada University (UGM) assessed that many articles in the Job Creation Law concern land clusters with substantive and formal problems. The Job Creation Law, will cause many problems in agrarian issues. In contrast to Prof. Maria and Eko Cahyono, Sofyan Djalil, as the Minister of Agrarian Affairs and Spatial Planning / BPN, explained the question of "how important" omnibus law is. By 'fixing' 79 conflicting laws through the Job Creation Law, the investment climate will be easier. That way, investors are willing to invest in Indonesia, they don't need to deal with many permits which are considered complicated (Sadono, 2010).

Then, referring to the Basic Agrarian Law, said Eko, it is clear that land has a social function. It cannot be traded and cannot be commodified. The creation of a land bank, he said, was an unconstitutional act. Viewed from the side of political law. According to Eko, the ratification of the Job Creation Law shows that legal politics seeks to bypass various regulations, remove bottlenecks or all barriers to investment in Indonesia. With the assumption, Indonesia's economy will suffer if investment does not come in.

Agrarian Activist Sajogjo Institute invites to look at the findings of the KPK in the national movement to save natural resources, which clearly shows the inhibition of investment as a corruption so the conditions and processes are already corrupt. Then answered by omnibus law that has a high potential for corruption. actually want to use investment for economic growth with the main problem of the law is corruption. This instead legalizes the omnibus law which has the potential to perpetuate corruption.

According to thrifty authors, so far many government agencies use the land under its control for business purposes, while the UUPA asserts that for the benefit of government agencies are given special usage rights for public services are not commercial. And of course, this clearly violates the conception of the right to control the state on land, and this condition as Eko's opinion above, can actually be a potential corruption, although the desire to trim the licensing process is expected to facilitate and accelerate the acquisition of rights for investors.

\section{Research methods}

This type of research is a legal research, which is a research conducted through a way of reviewing the rules and laws that apply to answer the legal problems studied. Legal 
research is a research by analyzing the rule of law and law based on dogmatic law, legal theory, and legal philosophy. Problem formulation in this study:

How is the Implementation of Management Rights within a period of 90 years that has an impac

How is the Development of Management Rights up to the management of the Land Bank Institution?t on violations of the Constitution?

\section{Results and discussion}

The development of National land management rights as a legitimate control based on people's welfare. In advancing the reform of the National Land Law the government has a number of details in the improvement so that it can face the era of globalization, which today has felt its influence in the field of activities and control over a right to land. The right to control of the country is the authority to (Harsono, 2007):

- regulate and organize the allocation, use, provision and maintenance of the earth, water, and space

- determine and regulate the relationships of people with the earth and others (in other words the state is authorized in determining and regulating civil rights and other rights obtained on the earth).

- determine and regulate the legal relationships between people and legal acts that exist in the context of the earth, water and space (Article 2 paragraph (2)) authority that is sourced on the right of control of the country, used later to achieve the prosperity of the people in the sense of nationality, welfare and independence in an independent, sovereign, just and prosperous Indonesian society and legal state (Article 2 paragraph (3)).

In the implementation of the right to power from the country is authorized to the swatantra region that is autonomous so that there needs to be anti-opposition in the indigenous legal community, the government and businesses that focus on development interests (Sukirno, 2006), so that state power is only limited to the legitimacy of power which gives authority to land owned by a person with a right, be it property right, right to cultivate, right to build or use right according to its designation and needs or to give it in management to a ruling body to be used for implementation of their respective duties so that the points of Article 2 paragraph (3) can be administered and mandated by law in accordance with their designation, namely the welfare of the entire community. Talking about land use rights, one of which is quite controversial, namely the Management Rights granted 90 years for foreign investors, the most feared thing is that there is a monopoly in terms of objectives that can have fatal consequences for the administration of government itself and the defense system itself. Talking about land use rights, one of which is quite controversial, namely the Management Rights granted 90 years for foreign investors, the most feared thing is that there is a monopoly in terms of objectives that can have fatal consequences for the administration of government itself and the defense system itself. Management rights provide opportunities for collaboration with third parties. Article 6 regulates that the HPL holder can surrender parts of the land to a third party, with a usufruct of 6 years. HPL holders are widened again by article 7 which regulates that in addition to the agencies mentioned in Article 4, management by the Minister of Agrarian Affairs can also be given to other agencies which to carry out their duties require control of state lands, 
with this authority in Article 6. Article 5 PMA 9 of 1965 stipulates that HPL is given when state land is not only used by the agency given the right, it is also intended for cooperation with third parties. Article 6 regulates the authority of the HPL holder in addition to making plans, also to use the land to carry out their duties, and to hand over part of the land to a third party with a use right for a period of 6 years.

From the shadowy foundations of the concept in the UUPA, the role of HPL is increasingly clarified in the next implementing regulation, even the concept which is shaky its footing is used as the basis for regulating in the form of a law. For example, Law Number 16 of 1985 concerning Flats, and Law Number 21 of 1997 concerning Fees for Acquisition and Acquisition of Rights to Land and Buildings. In the explanation of the UUPA it is emphasized that according to Article 33 of the 1945 Constitution, the state does not need to act as the owner of the land, only has the power to regulate. For this reason, the state has the authority to grant rights to individuals or legal entities, in the form of property rights, HGU, HGB, or use rights, or to give them in management to a ruling body (department, service, or autonomous area) to be used for carrying out their respective duties. -Each, according to article 2 paragraph 4 . This is where the word management first appeared, although it has shifted somewhat from Article 2 paragraph 4 of the UUPA, and there are still limitations that management is still related to the duties of each agency assigned the management task. Article 2, paragraph 4 reads: "The right to control of the state above its implementation can be exercised in autonomous regions and customary law communities, only necessary and does not conflict with national interests, according to the provisions of government regulations". the conception of flats and violates the principle of horizontal separation and the principle of the UUPA regarding land rights for foreigners. Furthermore, in Law no. 20 of 2011 concerning Flats emphasizes the difference between flats standing on leased land and those standing on private land, in this case HGB and HP. Flats on leased land, can be rented or owned by anyone: Indonesian citizens / foreigners, Indonesian legal entities / foreign legal entities because they do not involve joint ownership of land. Proof of rights in the form of Building Ownership Certificate (SKBG) because what is owned is only the building / building. SKBG is issued by the Government of 83 Regency / City. It is different if the apartment is on HGB / HP land, where there is individual ownership of the unit / flat / apartment, as well as joint ownership of the land, building, and part of the apartment concerned. Proof of ownership rights in the form of a Certificate of Ownership on a Flat Unit (HMSRS Certificate) issued by a land agency.

It is somewhat surprising that the Minister of ATR made the following statement: that the right to use for the apartment is considered to be an obstacle for foreigners working in Indonesia. It is stated that the foreigner needs the space (meaning: the building), the foreigner buys an apartment without land. This statement is "miraculous" because consciously or not, what the Minister of ATR means is an apartment that stands on leased land. Even without special rules made by law, there is no problem if foreigners buy an apartment that stands on leased land. This statement is in accordance with the definition of a flat in Article 143. However, it is different from what was stated by the Minister of ATR, which is also regulated in the Law, which indicates that it is permissible for foreigners and foreign legal entities to have flat units on HGB land (Article 145). guarantees that shared land with HGB status can be granted extension and renewal of rights after obtaining a Certificate of Acceptability of Function (notes on this can be checked in the previous description). Realizing that what is regulated in this law is contrary to the UUPA and the 
Law on Flats (UURS), then in the Elucidation of the Law it is stated that this provision only applies in Special Economic Zones (KEK).

The question is, does the existence of KEK give legitimacy to make regulations that contradict the UUPA, UURS, and other related regulations? Is KEK a "state within the state", or vice versa, is it not included in the territory of the Republic of Indonesia so that it does not submit to the legal jurisdiction of the Republic of Indonesia? Who can guarantee that the rules for the ownership of flats by foreigners in this law are not followed by developers outside the KEK, so that violations of the principles of the UUPA and UURS are also legal for locations outside the KEK?

The second feature of HGB over HPL is that it specifically regulates ownership of apartment units whose shared land has the status of HGB above HPL for foreigners and foreign legal entities (Articles 143-145). Logically, with the opening of the investment door, it is necessary to provide the possibility of owning an apartment for foreigners working in Indonesia. The definition of flats is twisted in such a way, deliberately obscuring the notion of flats that stand on leased land and flats that stand on land rights, in this case HGB and Use Rights. Overall Articles 143-145 stipulate that foreigners and foreign legal entities can own flats standing on HGB land, which clearly violates the conception of flats and violates the principle of horizontal separation and the principle of UUPA regarding ownership of land rights for foreigners. Furthermore, in Law no. 20 of 2011 concerning Flats emphasizes the difference between flats standing on leased land and those standing on private land, in this case HGB and HP. Flats on leased land, can be rented or owned by anyone: Indonesian citizens / foreigners, Indonesian legal entities / foreign legal entities because they do not involve joint ownership of land. Proof of rights in the form of Building Ownership Certificate (SKBG) because what is owned is only the building / building. SKBG is issued by the Government of 83 Regency / City. It is different if the apartment is on HGB / HP land, where there is individual ownership of the unit / flat / apartment, as well as joint ownership of the land, building, and part of the apartment concerned. Proof of ownership rights in the form of a Certificate of Ownership on a Flat Unit (HMSRS Certificate) issued by a land agency.

It is somewhat surprising that the Minister of ATR made the following statement: that the right to use for the apartment is considered to be an obstacle for foreigners working in Indonesia. It is stated that the foreigner needs the space (that is, the building), the foreigner buys an apartment without land. This statement is "miraculous" because consciously or not, what the Minister of ATR means is an apartment that stands on leased land. Even without special rules made by law, there is no problem if foreigners buy an apartment that stands on leased land. This statement is in accordance with the definition of a flat in Article 143. However, it is different from what was stated by the Minister of ATR, which is also regulated in the Law, which indicates that it is permissible for foreigners and foreign legal entities to have flat units on HGB land (Article 145). guarantees that shared land with HGB status can be granted extension and renewal of rights after obtaining a Certificate of Acceptability of Function (notes on this can be checked in the previous description). Realizing that what is regulated in this law is contrary to the UUPA and the Law on Flats (UURS), then in the Elucidation of the Law it is stated that this provision only applies in Special Economic Zones (KEK).

The question is, does the existence of KEK give legitimacy to make regulations that contradict the UUPA, UURS, and other related regulations? Is KEK a "state within the 
state", or vice versa, is it not included in the territory of the Republic of Indonesia so that it does not submit to the legal jurisdiction of the Republic of Indonesia? Who can guarantee that the rules for the ownership of flats by foreigners in this law are not followed by developers outside the KEK, so that violations of the principles of the UUPA and UURS are also legal for locations outside the KEK?. it should be a special economic policy that focuses on countries in asean, especially Indonesia, to prioritize the analysis of the application of the policy itself, not necessarily to apply it without clear boundaries, causing confusion, one of which is disturbing stability to chaotic overlapping of reducing the national legal system.

\section{Land Bank as a Provider of Land for the Allocation of National Development Goals in the Economic Sector}

If seen also in the government's plan to manage land assets in order to increase investment cooperation by investors, it is considered to impose land redistribution for the community, especially the lower class, the institution is considered to be able to synergize in achieving the objectives of development programs with economic objectives so that it can clarify the role of government institutions in the welfare of the people. . There are also institutions in the form of a Land Bank which was formed as an institution that provides land not only for civil society but also for business actors such as investors. If the Land Bank was primarily formed to provide land to investors in the hope of creating the widest possible employment opportunities, the question is, where did the land for the investor come from? Of course, from the results of land acquisition originating from community land and customary law communities (MHA). If this happens, then the community and the MHA who originally owned land and obtained the results / production from working or taking advantage of and exploiting land and other natural resources in the environment where they live / work and / or within their territory, with compensation given, they have relocated. independently, far from the original place of residence, without the certainty of obtaining socio-economic welfare that is at least equal to the previous conditions.

Those who previously were able to live from working in agriculture and other jobs in rural areas, as well as MHA could support themselves independently without assistance from the government, could very well lose their jobs because they have to organize their life in a new place. The impact is certainly worse for women as household heads who are forced to make a living in a new place. If the location which later became the authority of the Land Bank was provided for investors, and if later factories and other forms of business activities were built, would it be possible to create the widest possible job opportunities. Must see:

- First, is it impossible for the available employment opportunities to absorb as many workers as possible. It must be limited because there are conditions that must be met by prospective workers and this is very reasonable.

- Second, then, what about the fate of the former holders of land rights / MHA whose land was released to be controlled by BT.

It is unlikely that they will be absorbed in new employment opportunities, either because of the distance from where they live, or the fulfillment of the requirements to be accepted as a workforce. This phenomenon can be understood as "creating jobs" by eliminating existing jobs. The labor force that is absorbed is limited and is likely to come more from 
"outside" (not from local communities whose land has been taken over to be used as areas for economic development).

Without empowerment for former rights holders / MHAs, through regulations on the need for monitoring and evaluation of former rights holders / MHAs to ensure that their economic welfare does not diminish after relocating independently from their original place, the opening of employment by investors will not affect the fate of the majority. former rights holder / MHA who left their land in the interest of providing land for investors through BT. To smooth out the big scenario that begins with the formation of BBT, BBT is given HPL status (Goesniadhie, 2010). If the Land Bank was primarily formed to provide land to investors in the hope of creating the widest possible employment opportunities, the question is, where did the land for the investor come from? Of course, from the results of land acquisition originating from community land and customary law communities (MHA) (Kusumaadtmadja, 2006). If this happens, then the community and the MHA who originally owned land and obtained the results / production from working or taking advantage of and exploiting land and other natural resources in the environment where they live / work and / or within their territory, with compensation given, they have relocated. independently, far from the original place of residence, without the certainty of obtaining socio-economic welfare that is at least equal to the previous conditions.

Those who previously were able to live from working in agriculture and other jobs in rural areas, as well as MHA could support themselves independently without assistance from the government, could very well lose their jobs because they have to organize their life in a new place. The impact is certainly worse for women as household heads who are forced to make a living in a new place. If the location which later becomes the authority of the Land Bank is provided to investors, and if a factory is later built and other forms of business activities, whether it can create the widest possible job opportunities, it must be considered:

- First, is it impossible for the available employment opportunities to absorb as many workers as possible. It must be limited because there are conditions that must be met by prospective workers and this is very reasonable. Second, then, what about the fate of the former holders of land rights / MHA whose land was released to be controlled by BT.

It is unlikely that they will be absorbed in new employment opportunities, either because of the distance from where they live, or the fulfillment of the requirements to be accepted as a workforce. This phenomenon can be understood as creating jobs by eliminating existing jobs. The labor force that is absorbed is limited and likely comes from outside (not from local communities whose land has been taken over to be used as an area for economic development). Without empowerment for former rights holders / MHAs, through regulations on the need for monitoring and evaluation of former rights holders / MHAs to ensure that their economic welfare does not diminish after relocating independently from their original place, the opening of employment by investors will not affect the fate of the majority. former rights holder / MHA who left their land in the interest of providing land for investors through BT. To smooth out the big scenario that begins with the formation of BBT, BBT is given HPL status. Meanwhile, the authority of the Land Bank Agency as the holder of HPL is wider compared to the authority of non-BBT HPL holders. Non-BBT HPL holders have the authority regulated in Article 137 paragraph (2), namely: 
- compiling a plan for the designation, use and utilization of the land in accordance with the spatial plan;

- use and utilize all or part of the HPL land for own use or in cooperation with third parties; and

- determine the tariff and receive income / compensation and / or mandatory annual money from third parties in accordance with the agreement.

As a note, it can be stated that the content of Article 137 paragraph (2) has undergone a modification of the authority of the HPL holder according to the previous regulation (PMA No.9 of 1965 y.o Permendagri No.5 of 1974; Permendagri No.1 of 1977). In the Law, the authority of the Land bank Agency as the holder of HPL in order to support investors is contained in Article 129 paragraph (4), namely:

- carry out the preparation of the master plan;

- help to facilitate Business Licensing / Approval;

- carry out land acquisition; and

- determine service rates.

Thus it can be said that the Land Bank Agency has the authority to hold HPL plus. As an HPL holder, when preparing land for BBT investors, they are authorized to help facilitate Business Licensing / Approval and determine service rates; as an HPL holder, if the HPL on behalf of BBT is collaborated with a third party, BBT can determine the tariff and receive the annual mandatory income and money. The management of the two sources of wealth mentioned above (service fees and income and annual mandatory fees) needs to be carried out in a transparent and accountable manner to prevent corruption from occurring in all its effects, including hindering investment. How do you make the land that has been obtained by the Land Bank Agency to be given to other parties, for example the Government / Regional Government, BUMN / BUMD. In Article 137 paragraph (4) it is stated that HPL can be released to other parties who meet the requirements. This provision should not be interpreted as direct release, but rather released for later on HPL land which has become state land can be given HPL on behalf of another party who meets the requirements. Excessive provisions can be found in Article 141 which states that in the context of controlling the use of land rights over HPL, within a certain period of time, an evaluation of the use of land rights is carried out. Why is it too much? Because it must be specifically regulated in law.

The question is, has so far the ATR / BPN not supervised and controlled all land rights that have been assigned, whether given on state land or on HPL land. The closing note on Land Bank is the regulation regarding the institutional structure of a Land Bank as stipulated in Articles 130-134. Judging from its structure, the BT Institution is dominated by the Ministry of ATR / BPN. The Chairperson of the Committee is held by the Minister of ATR, accompanied by members consisting of 86 Ministers and related Heads. The Chairperson and members of the Committee are determined by a Presidential Decree based on a recommendation from the Minister of ATR. This formula should have been split into two paragraphs. The Supervisory Board consists of 7 (seven) persons consisting of 4 (four) persons from professional elements selected by the Central Government, elected and approved by the DPR. And the 3 (three) people elected by the Central Government.

\section{Conclusion}


The land substance contained in Chapter VIII Part Four (Articles 125-147) of the Job Creation Law (UU) is proven not to simplify regulation because Law No.5 of 1960 (UUPA) as the original Law was not referred to for amendment / deletion. The formulation was prepared by copying the substance in the Land Bill, which discussion was postponed on September 23, 2019 due to crucial issues for which no solution has been obtained. The addition of the formula in the law actually adds to the complexity of its substance. The arrangement of land arrangements is based on large scenarios to open up investment opportunities through relatively easy land acquisition for business actors. For this reason, a Land Bank Agency was formed which would provide land and help provide Ease of Business Licensing / Approval. The position of the Management Rights (HPL) as a function was changed to become rights because it was used as a basis for the rights of third parties to run their businesses by obtaining Land Rights over the HPL. Building Use Rights (HGB) over HPL are used as the prima donna because the majority of types of development for investment require a right base in the form of HGB. Even though the HGB has not ended, an extension and renewal of rights can be given after obtaining a Proper Function Certificate (SLF). This provision has the opportunity to be submitted for review in the Constitutional Court. In particular, foreigners and foreign legal entities are allowed to own 89 apartments / sarusun whose shared land has HGB status.

Unfortunately, this scenario was drafted in violation of / contradicting the Constitutional Court Decision, TAP MPR IX / 2001, UUPA, and Nawacita especially the fifth program. On the other hand, mentioning Agrarian Reform (RA) as one of the objectives of the Land Bank has no impact on the redistribution of agricultural land. The Land Bank ideology is incompatible with the objectives of RA. Apart from being ambiguous, this provision has the potential to weaken the implementation of RA as stipulated in Presidential Decree No.86 of 2018 concerning Agrarian Reform. Therefore, the question of what the law actually means and the function of law in society can be returned to the basic question: what is the purpose of law. In the final analysis, the main objective of the law if it is to be reduced to one thing only is order. Order is the ultimate and first objective of all law. this need for order is a fundamental condition for the existence of an orderly human society. legal harmonization does not only concern matters that are intended to avoid overlapping or conflicting arrangements. in law harmonization defines efforts to harmonize objectives, strategies to achieve goals, and guidelines for implementing strategies so that the objectives of each statutory regulation can be achieved. Therefore, the importance of reviewing the concept of the Omnibus Law Work Creation Law into the basic regulations of the agrarian foundation which refers to several rules and decisions of Mk MPR IX / 2001 UUPA and Nawacita, especially the fifth program. On the other hand, mentioning Agrarian Reform (RA) as one of the objectives of the Land Bank has no impact on the redistribution of agricultural land. The Land Bank ideology is incompatible with the objectives of RA. Apart from being ambiguous, this provision has the potential to weaken the implementation of RA as stipulated in Presidential Decree No.86 of 2018 concerning Agrarian Reform. As well as the preparation of five RPPs for the implementation of the Law has the potential to increase legal uncertainty because the land substance in the Law is contrary to the original Law (UUPA) and the implementing regulations which are still fully valid. so that existing land regulations can be used to support investment. Improvements can be made as needed, without having to introduce 
new regulations that are problematic in law. To encourage investment, what must be done is to provide more professional, clean and responsible land services.

\section{References}

1. Goesniadhie, K. (2010). Harmonisasi Sistem Hukum: Mewujudkan Tata Pemerintah yang baik, Malang, Nasa Media.

2. Harsono, B. (1997). Hukum Agraria Indonesia : Sejarah Pembentukan UUPA dan pelaksanaannya, Jakarta, Djambatan.

3. . (2007). Menuju Penyempurnaan Hukum Tanah Nasional : Perkembangan Pemikiran dan Hasilnya sampai menjelang Kelahiran UUPA. Jakarta, Universitas Trisakti.

4. $\quad$ Kusumaatmadja, M. (2006). Konsep-konsep Hukum dalam Pembangunan. Bandung, P.T. Alumni.

5. Maria. (2008). Tanah dalam Perspektif Hak Ekonomi, Sosial dan Budaya, Jakarta, Buku Kompas.

6. Sadana, B. (2010). Politisasi Hak Pengelolaan (Hpl) Dalam Sistem Hukum Pertanahan Nasional.

7. Masalah-masalah Hukum, 39(4), 372-377. DOI: 10.14710/mmh.39.4.2010.372-377

8. $\quad$ Sukirno, S. (2006). Ekonomi Pembangunan : Proses, Masalah, dan Dasar Kebijakan. Jakarta, PT Prenada Media Group.

9. Law and Regulation

10. Indonesia, The Constitution of the Republic of Indonesia

11. Indonesia, Basic Agrarian Law No. 5 of 1960

12. Indonesia, Government Regulation No. 40 of 1996 concerning Business Use Rights, Building Use Rights and Land Rights.

13. Indonesia, UU no. 20 of 2011 Concerning Flats as an amendment to Law Number 16 of 1985 concerning Flats

14. Indonesia, Law concerning Foreign Investment number 9 of 1965

15. Indonesia, Decision of the Constitutional Court MPR IX / 2001 UUPA Creative Commons Attribution - Non Commercial - No Derivatives 4.0 International License. 